\title{
DOŚWIADCZENIE PARENTYFIKACJI W RODZINIE JAKO WYZWANIE DLA PRACY SOCJALNEJ
}

\author{
Abstract \\ The experience of parentification in families as a challenge for social work
}

Family is the natural environment of life and development for every human being. The family home shapes us and equips us for the long journey of a our further, independent living. All difficulties occurring in it have a significant impact on the functioning of the family environment and its individual members. This article addresses the issue of parentification, which could be an inspiration and challenge for social work. "Small heroes" taking up adult roles in their childhood, actions exceeding their own power, actions usually not ascribed to the role of a child, grow on "mature children", who still carry on their shoulders burdens (usually emotional) of responsibility for family and parents. Reflections presented here concern the experience of parentification in narration of parentified children from adult perspective. It emphasizes importance of their own individual views and evaluation of these experiences and also places it in their biography.

Key words: parentification, families, social work

\section{Wprowadzenie}

W artykule podjęto problematykę odwrócenia ról wewnątrzrodzinnych, inaczej parentyfikacji. Polega ona na przejmowaniu przez dzieci zadań, obowiązków i odpowiedzialności przypisanych osobom dorosłym w rodzinie - rodzicom. Jest to zjawisko będące elementem funkcjonowania całego systemu rodzinnego i zwykle uwarunkowane dążeniem do utrzymania jego trwałości. Osoby parentyfikowane w dzieciństwie określa się mianem „dorosłych dzieci”, co może być rozumiane dwojako - w odniesieniu do dzieci, które musiały stać się dorosłe, przyjmować postawy dojrzałe i odpowiedzialne, oraz w odniesieniu do osób już dorosłych, które nie mogły przeżywać swego dzieciństwa z powodu odwróconych ról rodzinnych, co skutkuje brakiem zdolności do realnego pełnego życia w dorosłości.

Celem niniejszych rozważań jest zaprezentowanie zjawiska parentyfikacji jako trudnego doświadczenia rodzinnego, które może stanowić inspirację i wyzwanie dla działań w pracy socjalnej. Poznanie bowiem funkcjonowania rodziny stanowi podstawę do konstruowania działań zarówno profilaktycznych, jak i pomocowych. Praca 
z rodziną to nie tylko dbałość o jej finansowy byt, ale też troska o stabilność środowiska rodzinnego - stabilność bazującą na realizacji potrzeb jej członków, zwłaszcza dzieci.

Przyjęta biograficzna perspektywa badawcza pozwala na podjęcie próby rozpoznania tego zjawiska w kontekście całożyciowym osób, których dotyczy. Na podstawie uzyskanych narracji autobiograficznych możliwe okazuje się scharakteryzowanie okoliczności występowania parentyfikacji, przebiegu, konsekwencji i jej znaczenia dla osób jej doświadczających.

\section{O zjawisku parentyfikacji}

Terminem „parentyfikacja” (pojęcie stworzone przez psychiatrów Ivana Böszörményi-Nagy'ego oraz Geraldine Spark w latach siedemdziesiątych XX wieku) określa się zjawisko odwrócenia ról w rodzinie, mające charakter instrumentalny bądź emocjonalny. Dochodzi do niego wówczas, gdy dziecko przejmuje odpowiedzialność za fizyczne i psychiczne potrzeby członków rodziny, pełni rolę opiekuna czy partnera rodzica, co w znaczący sposób przekracza jego możliwości (Schier 2015). Parentyfikacja emocjonalna odnosi się do sytuacji, w których dziecko podejmuje rolę powiernika, bufora, terapeuty, partnera czy mediatora w rodzinie w trosce o równowagę w rodzinie (czy jej psychiczny dobrostan). Odwrócenie ról o charakterze instrumentalnym obejmuje zaspokajanie fizycznych i materialnych potrzeb rodziny, np. poprzez podejmowanie pracy zarobkowej, opiekę nad rodzeństwem czy chorym rodzicem, wypełnianie obowiązków domowych (gotowanie, sprzątanie, zakupy) itp. (Schier 2015). Należy zaznaczyć, że zamiana ról czy ich odwrócenie zachodzą zwykle na linii rodzice-dziecko.

Wydaje się istotne dokonanie rozróżnienia między parentyfikacją a innymi zjawiskami wynikającymi ze wzajemnej pomocy wewnątrzrodzinnej, oczekiwaniami stawianymi wobec dziecka w trudnej i przejściowej sytuacji rodziny czy też działaniami o charakterze i znaczeniu wychowawczym. Można bowiem stawiać tu słuszne pytanie: co jest parentyfikacją, a co jeszcze nią nie jest? Zwraca na to uwagę również Stéphanie Haxhe (2016), wyróżniając trzy procesy zbliżone do parentyfikacji, ale odróżniające się od niej kilkoma aspektami, a mianowicie: oczekiwaniami rodziców wobec dziecka, rodzajem podejmowanych obowiązków i odpowiedzialności oraz kontekstem sytuacyjnym, w którym do niego dochodzi. Należą do nich parentalizacja (parentalization), adultyzacja (adultilization) oraz delegacja (delegation). Pierwsza z wymienionych - parentalizacja odnosi się do sytuacji, w których dziecko towarzyszy rodzicom w wypełnianiu ich rodzicielskich zadań. Nie wykracza to jednak poza możliwości i kompetencje dziecka, sprzyja natomiast jego rozwojowi. Adultyzacja zaś to swego rodzaju nakłanianie czy zachęcanie dziecka do przejścia ku dorosłości, uzyskania autonomii i samodzielności, bez narzucania mu ról rodzicielskich. Ostatni z procesów - delegacja - to powierzenie dziecku zadania do zrealizowania, które nadaje sens i kierunek jego dziecięcemu życiu. Traktowane przez nie jako misja, bywa także wynikiem przeniesienia na dziecko przez rodzica własnych niezrealizowanych ambicji czy problemów, marzeń i celów. 
Delegacja może przekształcić się w parentyfikację, jeśli zadania będą niedostosowane do możliwości dziecka.

W rozważaniach na temat odwrócenia ról w rodzinie konieczne jest właściwe rozpoznanie problemu. Odróżnić tu należy sporadyczne i normatywne podejmowanie opieki nad rodzicami (rodzeństwem) od regularnego realizowania potrzeb czy oczekiwań członków rodziny. Pierwsze może być bowiem elementem stymulującym dziecko do rozwoju w różnych sferach życia, aktywności twórczej, samodzielności, działań społecznych, a co za tym idzie do samorozwoju (Rostowska, Borchet 2016). Drugie ma charakter uogólniony i dewiacyjny, spełnia funkcje kompensacyjne, adaptacyjne oraz obronne i niesie z sobą wiele negatywnych konsekwencji (Grzegorzewska 2016). Jednakże granice pomiędzy adaptacyjnymi a destrukcyjnymi formami odwrócenia ról nie są wyraźne. Doświadczenia przenikają się, a wskazane kryteria i stopnie nasilenia pomagają jedynie zaobserwować ich ryzyko lub stan dokonany (skutki).

Jak zauważa Salvador Minuchin i inni (Minuchin, Montavalo, Guerney jr, Rosman, Schumer 1967), nie każda zamiana ról w rodzinie ma charakter patologiczny, ale każdy rodzaj parentyfikacji stanowi zakłócenie prawidłowego funkcjonowania rodziny, co może wywołać negatywne konsekwencje dla dziecka. Wyróżnia się konkretne kryteria warunki, które muszą być spełnione, by można było mówić o parentyfikacji:

1) tylko jedno dziecko przejmuje odpowiedzialność za rodzica i rodzinę (realizuje obowiązki opiekunów);

2) obowiązki są nieadekwatne do poziomu rozwoju i wieku dziecka;

3) wykonywanie obowiązków rodzica utrudnia realizację przez dziecko własnych zadań rozwojowych i zaspokajanie potrzeb;

4) dzięki podejmowaniu tych zadań dziecko otrzymuje od rodzica uwagę i miłość;

5) niejasna struktura władzy w rodzinie, zatarte granice pomiędzy subsystemami (rodzic-dziecko) (Grzegorzewska 2016).

Badacze zajmujący się zjawiskiem parentyfikacji zwracają uwagę na fakt, że jest ono powszechne i obecne w życiu dzieci. W krajach anglojęzycznych, takich jak USA, Wielka Brytania czy Australia, problem ten dotyczy czworga na sto dzieci do 18. roku życia (Becker 2007). Badania angielskie dotyczące rodzin, w których jedno z rodziców jest przewlekle chore lub niepełnosprawne, pokazują, że w Wielkiej Brytanii co najmniej 50 tys. dzieci, które nie ukończyły 18. roku życia, sprawuje długotrwałą opiekę nad chorymi rodzicami (Earley, Cushway 2002). Opieka, którą otaczają swoich rodziców, ma przeważnie charakter regularny i systematyczny, dotyczy całego zestawu zadań: od prowadzenia gospodarstwa, poprzez troskę o pozostałych członków rodziny, wykonywanie dodatkowych prac zarobkowych, na licznych czynnościach pielęgnacyjnych naruszających sferę intymną w relacjach rodzic-dziecko kończąc.

Natomiast badania polskie, realizowane przez Jolantę Żarczyńską-Hylę i zespół (2016), przedmiotem zainteresowania czynią uwarunkowania zjawiska parentyfikacji w dzieciństwie oraz okresie dorastania z perspektywy młodych dorosłych. Czynniki sprzyjające odwróceniu ról w rodzinie zostały podzielone na: czynniki losowe, sprawcze związane z cechami i zachowaniami rodziców oraz czynniki socjodemograficzne. Przeprowadzone 
wstępne badania wśród studentów kierunków pedagogicznych wykazały istnienie związków między poszczególnymi rodzajami parentyfikacji a konkretnymi aspektami kontekstu rodzinnego. Wykazują też, że doświadczenie intensywnej parentyfikacji dotyczy około jednej piątej badanych studentów.

Parentyfikacja jawi się jako zjawisko szczególnie istotne w kontekście przemian dotykających współczesne polskie rodziny. Jak pokazują badania, rodzina i szczęście rodzinne niezmienne stanowią najważniejsze wartości, jakimi Polacy kierują się w swoim codziennym życiu (Boguszewski 2013). Jednakże ulegają one niepokojącym przeobrażeniom, takim jak: wzrost wskaźnika rozwodów i separacji, zwiększona liczba rodziców samotnie wychowujących dzieci lub wzrost liczby rodzin zrekonstruowanych, opóźnianie decyzji matrymonialnych, wstrzymywanie się od prokreacji lub całkowita rezygnacja z posiadania dzieci, wzrost liczby jednoosobowych gospodarstw domowych, a także coraz większa popularność związków nieformalnych (także wychowujących dzieci) (Boguszewski 2013). Występowaniu odwrócenia ról w rodzinie sprzyjają takie problemy obserwowane w polskich rodzinach, jak: choroby opiekunów, uzależnienia, wysoka konfliktowość, niskie kompetencje rodzicielskie, brak spójności w rodzinach, naruszający tradycyjne granice i więzi, a także brak stabilizacji ekonomicznej rodziny. Istotnym elementem wpływającym, a nawet kształtującym życie rodzinne jest także wielość informacji docierających do wszystkich członków rodziny za pośrednictwem mediów. Pogłębia ona pewnego rodzaju zagubienie i niepewność środowiska rodzinnego i jego poszczególnych uczestników. Rozwojowi zjawiska parentyfikacji towarzyszy także niekorzystna sytuacja socjoekonomiczna kraju, która stanowi główną przyczynę zagranicznych wyjazdów jednego lub obojga rodziców w poszukiwaniu pracy zarobkowej, co z kolei zaburza więzi emocjonalne rodzica z dziećmi i często wymusza na dzieciach przejmowanie roli rodzicielskiej.

Doświadczenie parentyfikacji jest przeżyciem trudnym, gdyż zazwyczaj nieuświadomionym, nieujawnionym i, co więcej, akceptowanym społecznie. Tak zwane dzielne dzieci traktuje się jako wyjątkowe, zaradne, wspierające rodzinę, godne uznania czy pochwały. Takie „bohaterstwo” stanowi jednak dla nich samych obciążenie przekraczające ich możliwości. Dźwigają na swych barkach odpowiedzialność (instrumentalną lub emocjonalną) za rodzinę (rodziców, rodzeństwo), co stanowi wyzwanie ponad siły.

\section{Podstawy metodologiczne badań własnych}

W podejmowanych badaniach własnych, osadzonych w paradygmacie interpretatywnym, zamierzano rozpoznać, jakie jest i na czym polega doświadczenie parentyfikacji w rodzinie. Przedmiotem zainteresowania stają się zatem subiektywne relacje osób parentyfikowanych w odniesieniu do ich życia i sytuacji rodzinnej. Doświadczenie odwrócenia ról rodzinnych jawi się jako zjawisko, mechanizm oraz zespół zachowan, które zachodzą w biegu życia człowieka, a zatem stanowią element jego biografii, w różny sposób ją kształtując. 
Przyjęta zatem perspektywa biograficzna pozwala na uchwycenie podmiotowego charakteru przedmiotu badań. Jak stwierdza Danuta Lalak (2010: 259): „Badania biograficzne (...) otwierają naukom społecznym drogę do społecznej rzeczywistości, w której musi być uwzględniona indywidualność aktora, a indywidualność ta jest z kolei ustrukturalizowana i uwarunkowana społecznie". Biografia człowieka staje się swoistą płaszczyzną refleksyjnej integracji wszelkich aktywności życiowych: poznania, działania, komunikowania, spotkania z innymi, co wpływa pogłębiająco na samoświadomość i zdolność do biograficznego uczenia się. W ujęciu naukowopoznawczym biografia jest pewną subiektywną konstrukcją przeżytego życia (Lalak 2010).

Jako główną technikę gromadzenia danych wybrano autonarracyjny wywiad biograficzny Fritza Schützego, za pomocą którego badacz może poznać indywidualne postrzeganie świata, najbliższego otoczenia i doświadczeń przez uczestnika badań. Badany przedstawia swoją przeszłość - bieg swojego życia z własnego punktu widzenia. Człowiek jest aktywnym podmiotem, „który ustawicznie interpretuje swoje doświadczenia i docierające do niego informacje, negocjuje sens zdarzeń i obiektów w spotkaniu z innymi podmiotami” (Urbaniak-Zając, Kos 2013). W podejściu biograficznym przedmiotem badań staje się życie konkretnego człowieka przedstawione przez niego w postaci narracji.

Narracja, którą w trakcie wywiadu konstruuje, może być postrzegana jako forma wypowiedzi - kompletna (obejmująca całe życie) lub tematyczna (odnosząca się do jego fragmentu lub konkretnego okresu problemowego), w której jednostka wyraża sposób, w jaki rozumie siebie i własną sytuację w kontekście doświadczanych wydarzeń. Prezentowanie własnych przeżyć w formie narracji stanowi dla badanego jeden ze sposobów poznawania rzeczywistości, w której funkcjonuje i którą współtworzy (Trzebiński 2002: 17). Podczas opowiadania o zdarzeniach ze swojego życia jednostka poddaje swoje doświadczenia refleksji oraz je interpretuje.

W celu usystematyzowania eksploracji zagadnienia postanowiono odpowiedzieć na następujące pytania:

1. Jakie były okoliczności podjęcia przez badanych ról właściwych rodzicom?

2. Jak przebiegał proces/doświadczenie parentyfikacji według rozmówców?

3. Jakie zjawiska i procesy towarzyszyły doświadczeniu odwrócenia ról w rodzinie?

4. Jakie indywidualne i rodzinne konsekwencje parentyfikacji dostrzegają badani?

Wybór powyższych pól zainteresowania uzasadniony jest potrzebą zaprezentowania podstawowych aspektów doświadczenia parentyfikacji. Wynika również ze wstępnej analizy uzyskanego materiału badawczego. Takie ujęcie problemu pozwoli na względnie całościowe jego zaprezentowanie.

W przypadku realizowanych badań proszono rozmówców o opowiedzenie historii swojego życia, ze szczególnym uwzględnieniem rodziny pochodzenia. Badacza interesowało bowiem, jak osoby, które doświadczyły parentyfikacji, przedstawiają je z perspektywy czasu - już jako dorośli - oraz jak ją umiejscawiają we własnej biografii. Pozyskane indywidualne historie i subiektywnie nadawane znaczenia pozwalają, po pierwsze, na 
poznanie zjawiska parentyfikacji jako istotnego w życiu rodzinnym i dorosłym jednostki, po drugie, na uznanie go za istotne w kontekście pracy socjalnej z rodziną na jej rzecz.

\section{Doświadczenie parentyfikacji}

Katarzyna Schier podkreśla, że: „Im wcześniej w życiu dziecka dochodzi do zjawiska parentyfikacji, tym skutki dla jego rozwoju są poważniejsze” (Schier 2012: 66, za: Jurkovic 1997). Odwrócenie ról rodzinnych należy zatem analizować jako doświadczenie jednostkowe, zwracając przy tym uwagę na charakterystyczne cechy, różnicujące jego przebieg oraz konsekwencje. Należą do nich: czas trwania parentyfikacji, jej przedmiot i podmiot, podejmowana rola, kryterium ciężkości, stopień internalizacji przez dziecko przypisywanej mu roli w rodzinie, kontekst kulturowy, sytuacja rodzinna, ocena proporcji na linii dawanie $v s$ branie (Schier 2015). Uzasadnione więc wydaje się ujęcie doświadczenia parentyfikacji w perspektywie biograficznej i poznawanie go w historii życia badanych osób.

Wytworzone w sytuacji wywiadu narracje przez rozmówców stanowią całościowe odzwierciedlenie życia oraz funkcjonowania w rodzinie pochodzenia $\mathrm{z}$ ich własnej perspektywy. Osoby zostały wyłonione na podstawie uwarunkowań sprzyjających występowaniu parentyfikacji, do których należą: psychiczne zaburzenia rodziców, alkoholizm, uzależnienia, kryzys małżeński, samotne rodzicielstwo, chore lub niepełnosprawne rodzeństwo, a jako konsekwencje wskazują m.in. depresję, aleksytymię czy zaburzony obraz własnego ciała (Schier 2015). Są to tzw. grupy ryzyka, będące kryteriami doboru rozmówców do badania.

Przytoczone tu zostaną wstępne wyniki analiz wyłaniające się z uzyskanych wywiadów, a odnoszące się do indywidulanego doświadczenia parentyfikacji. Dostrzegalne są zatem okoliczności odwrócenia ról w rodzinie, mechanizmy ich przebiegu, zjawiska towarzyszące oraz konsekwencje indywidulane i rodzinne. Doświadczenie parentyfikacji zostanie tu zatem zaprezentowane $\mathrm{w}$ wymienionych czterech sferach, będących odpowiedzią na postawione wcześniej pytania badawcze.

\section{Okoliczności odwrócenia ról w rodzinie}

Wśród okoliczności należy wskazać sytuację, w której znalazła się dana rodzina, jej wewnętrzne problemy mające charakter pierwotny względem zjawiska odwrócenia ról $\mathrm{w}$ rodzinie oraz społeczno-kulturowe umiejscowienie funkcjonowania rodziny ( $\mathrm{w}$ rozumieniu wymogów odnoszących się do relacji wewnątrzrodzinnych). Wśród badanych znalazły się zatem osoby z rodzin dotkniętych uzależnieniem rodzica (także rodzeństwa), chorobą psychiczną bądź fizyczną i niepełnosprawnością, z rodzin wielodzietnych, monoparentalnych (sytuacja samotnego rodzicielstwa spowodowana śmiercią rodzica lub rozwodem), z rodzin, w których rodzice byli nieobecni z powodu aktywności zawodowej 
(wyjazdy zarobkowe i nie tylko). Wskazane okoliczności stanowiły też podstawę doboru badanych, są one bowiem traktowane jako grupy ryzyka wystąpienia parentyfikacji, predysponujące do odwrócenia ról jej członków. W ich ramach dostrzeżono określone procesy niejako te okoliczności wzmacniające pod kątem inwersji ról. Nie w każdej bowiem rodzinie o danej sytuacji określonej jako ryzykowna odwrócenie ról rodzinnych wystąpiło czy wystąpi. Istotne tu okazują się swego rodzaju okoliczności dodatkowe, potęgujące zagrożenie odwróceniem ról.

Na podstawie analizy wywiadów wyłoniono następujące czynniki sytuacyjne współtowarzyszące występowanie zjawiska parentyfikacji:

1. Walka o przetrwanie, konieczność poradzenia sobie.

No i to był taki moment, kiedy po prostu automatycznie zacisnęłam zęby: no muszę sobie po prostu jakoś z tym poradzić. No i staram się zachować jakieś tam pozory normalności, organizować święta chłopakom (kobieta, 35 lat).

Widoczny tu jest swoisty instynkt przetrwania, ale niezatrzymujący się tylko na potrzebach indywidualnych, lecz rodzinnych. Dziecko, które w obliczu trudnej sytuacji bierze na siebie ciężar odpowiedzialności za rodzinę, próbuje organizować jej życie tak, by było jak najbardziej zbliżone do „normalności”. Osoba parentyfikowana próbuje kosztem własnych potrzeb zachować względną stabilność systemu rodzinnego.

2. Poczucie odpowiedzialności za nieszczęśliwe życie (związek, małżeństwo) rodziców - poczucie winy.

Teraz też tak powtarza, że ona tam była dla mnie, bo potrzebowałam ojca, ona chciała, żebym miała całą rodzinę, że tak lubiłam dziadków... no że... no tam było moje kuzynostwo, tak? Że dobrze się tam czułam, wiesz ktoś mi łachę zrobił tak? Że się tak poświęcił... i może nie było mi źle wtedy, najgorzej... (kobieta, 42 lata).

Dziecko niesie na swoich barkach przez całe życie poczucie winy za nieudany związek swoich rodziców, który najczęściej okazywał się koniecznością ze względu na ciążę. Do głosu dochodzą tu pewne normatywne nakazy społeczne, które niejako zmuszają młodych ludzi do zawarcia związku małżeńskiego w sytuacji pojawienia się dziecka. $\mathrm{W}$ takiej rodzinie dziecko zmaga się z destrukcyjną odpowiedzialnością, uznaje siebie za przyczynę nieszczęścia rodziców i wszelkich problemów z tym związanych.

3. Chęć zaspokojenia potrzeb emocjonalnych rodzica.

Ja chciałam mamę uszczęśliwić, bo moja mama zawsze się czymś martwiła, zawsze coś ją tam martwiło. Ja pamiętam właśnie takie wieczory, jak rachunki podlicza, czy jej będzie starczało pieniędzy i mi mówi o tym (kobieta, 43 lata). 
4. Bycie najstarszym dzieckiem w rodzinie.

Kwestia dużej rodziny i pojawiania się dzieci po kolei spowodowały, że ja jako najstarsza musiałam się nimi zajmować. To było takie największe cierpienie i żal, jaki miałam do rodziców w tym czasie (kobieta, 45 lat).

Wobec wielu obowiązków związanych z funkcjonowaniem rodzin wielodzietnych koniecznością okazuje się wspieranie rodziców w realizowaniu ich zadań. Zazwyczaj rola ta przypada najstarszemu dziecku w rodzinie. Staje się ono towarzyszem rodzica, jego oparciem. Zajęcie to absorbuje je tak bardzo, że uniemożliwia to realizowanie naturalnych dziecięcych potrzeb. Stwierdzić można, że osoba parentyfikowana, będąc owym wsparciem dla jednego z rodziców, zastępuje niejako drugiego, który jest zwykle fizycznie nieobecny w związku z koniecznością zarabiania pieniędzy.

5. Pragnienie zasłużenia na uwagę i miłość rodziców, realizacji ich oczekiwań i planów względem dziecka.

Moje dzieciństwo to było wieczne, od rana do wieczora, zastanawianie się, jak tu zrobić, jak tu wszystko zrobić, by sprostać tym oczekiwaniom mojej głównie mamy (kobieta, 39 lat).

Rodzice formułujący wobec dziecka rozmaite oczekiwania co do jego postawy, zachowań, przyszłości nakładają na jego barki ciężar konieczności sprostania im. Dziecko pragnie uczyć się wyłącznie dlatego, by rodziców uszczęśliwić oraz by utrzymać odpowiedni poziom bliskości z nimi. Staje się zatem osobą zaspokajającą ich potrzeby, często realizującą ich niespełnione aspiracje, pozostającą w oczekiwaniu na uznanie, uczucie, potwierdzenie miłości z ich strony.

Wymienione czynniki sytuacyjne dookreślają warunki wystąpienia odwrócenia ról w rodzinie, wyjaśniają w pewnym stopniu podjęcie przez dzieci zadań czy ról przypisanych osobom dorosłym. Nie były to zwykle działania świadome i zamierzone; wynikały raczej z konieczności, bliskości, poczucia zagrożenia trwałości rodziny, potrzeby zainteresowania. Zwraca tu uwagę owa troska o trwałość środowiska rodzinnego odczuwana przez dzieci. Potwierdzają się też założenia systemowego ujęcia rodziny, w którym celem jest utrzymanie rodzinnej homeostazy oraz istnienie sieci wzajemnych powiązań.

\section{Mechanizm zjawiska parentyfikacji}

Wskazane okoliczności wymuszają niejako na dziecku pełnienie określonych ról, co staje się niewątpliwie mechanizmem przywracania lub utrzymywania stabilności rodzinnej oraz kompensowaniem braków wynikających ze swoistej niewydolności rodzicielskiej. W badaniach własnych realizowane przez dziecko role wyodrębniono na podstawie ich indywidualnych relacji oraz znaczeń przypisywanych wykonywanym przez dziecko zadaniom. Dostrzeżono zatem, że parentyfikowane dzieci obejmują następujące role: 
1. Dziecko jako wsparcie instrumentalne, np. w opiece nad rodzeństwem, w wypełnianiu obowiązków związanych z prowadzeniem gospodarstwa domowego (pranie, sprzątanie, gotowanie itp.).

Moje koleżanki biegały po podwórku, no a mama, ponieważ tata pracował, więc... dzieci było dużo, więc ja miałam tam oczywiście wózki i były akcje dookoła bloku z tymi wózkami, pilnowania i wtedy kiedy moje koleżanki mogły wyjść na dwór, to ja musiałam na przykład pomagać mamie kąpać, pomagać mamie sprzątać... (kobieta, 45 lat).

Takie dziecko jest nieustannie zajęte obowiązkami domowymi, co uniemożliwia mu realizację dziecięcych potrzeb, zwłaszcza zabawy i spędzania czasy z rówieśnikami. Oczekiwania rodziców względem niego koncentrują się przede wszystkim na wypełnianiu obowiązków.

2. Dziecko jako powiernik rodzica.

Do mnie miał zawsze taki respekt, że w życiu nie podniósł ręki, był potulny jak baranek, ze mną zawsze lubił rozmawiać, jakbym była jego nie wiem... spowiednikiem? (kobieta, 37 lat).

Rodzic traktuje dziecko jako osobę, której się zwierza, z którą dzieli swoje troski. Dziecko stawiane jest wówczas na równi z osobą dorosłą, jako ktoś, kto może na swoje barki przyjąć ciężar jego trosk i problemów. Dokonuje się tutaj zamiana ról polegająca na tym, że rodzic staje się kimś słabszym, a dziecko musi być silne.

3. Dziecko jako obrońca.

Ja byłam w łazience i moja mama mnie woła po prostu, nie wiem, na pomoc? Ja wbiegłam, oni byli w moim pokoju i on tak stał po prostu z tą ręką wysuniętą i moją mamę nie wiem czy straszył, że ją uderzy (...) i ja wbiegłam między nich, po prostu stanęłam: wyjdź, wyjdź, wyjdź! (kobieta, 43 lata).

Dziecko staje przed koniecznością reagowania w sytuacji zagrożenia. Jest o pomoc wręcz proszone, wołane na ratunek. Staje pomiędzy skłóconymi rodzicami, zmuszone do obrony tego z nich, które jest w niebezpieczeństwie. Badani uzasadniają taką sytuację również w racjonalny sposób, twierdząc, że nie chcieli dopuścić do utraty (w przypadku np. śmiertelnego pobicia) ostatniej (zwykle matki, bo agresywny ojciec wielokrotnie tracił uznanie w oczach dziecka) bliskiej osoby.

4. Dziecko jako opiekun rodzica w chorobie.

Nie wiem i tak w głowie miałam to, że po prostu muszę się nią zajmować, że muszę, że w tym jest mój taki obowiązek, muszę coś zrobić i to jest ciężar, tylko to było coś takiego oczywistego, wiesz... że to jest oczywiste po prostu. No i pamiętam właśnie, jak ją uczyłam mówić, naprawdę to było niesamowite takie doświadczenie i trudne i takie wiesz łączące bardzo naprawdę (kobieta, 28 lat). 
W sytuacji choroby rodzica, w wyniku której zostaje on wyłączony z codziennego funkcjonowania, nie może wypełniać obowiązków domowych, opiekować się dziećmi, a co więcej, sam potrzebuje pomocy i pielęgnacji, uaktywniają się mechanizmy wzajemnej odpowiedzialności i lojalności rodzinnej. Dziecko lub dzieci przejmują zadania rodziców, role się odwracają: to chory rodzic staje się osobą potrzebującą opieki, a dziecko tym, kto może, a niekiedy nawet musi mu ją zapewnić. Choroba rodzica lub któregokolwiek z członków rodziny mająca charakter długotrwały oddziałuje na cały system rodzinny. Jeżeli dotyka rodzica, pojawiają się procesy wypełnienia luki systemowej - przejęcie jego zadań i obowiązków często przez dziecko. Natomiast jeśli chorzy są brat lub siostra, pozostałe dzieci zwykle pozostawiane są samym sobie, mają rodziców wspierać instrumentalnie i emocjonalnie, a nie oczekiwać od nich uwagi i zaspokajania potrzeb.

5. Dziecko jako administrator rodziny.

Dlatego my jako dzieci bardzo często byliśmy wykorzystywani jako pomoc słysząca, czyli gdzieś tam chodziliśmy do jakichś urzędów, do lekarzy, nie wiem jako na przykład ośmiolatka. Tata mi mówił, co ja mam powiedzieć, albo co załatwić, o co zapytać i ja robiłam. Także bardzo wcześnie umiałam sobie poradzić w takich sytuacjach urzędowych, w przychodni i tak dalej, i tak dalej (kobieta, 35 lat).

Wobec niewydolności czy pewnego rodzaju niepełnosprawności rodzica dziecko przejmuje zadania organizatora życia, co wiąże się również z koniecznością załatwiania spraw formalnych - urzędowych czy zdrowotnych.

6. Dziecko jako rodzic dla rodzeństwa.

Zajmowałam się tą moją najmłodszą siostrą i ona często mówiła do mnie «mamo». W ogóle wołała mamę na przykład, przychodziła mama do pokoju, to mówiła: nie ty mama, tylko ta druga mama, na przykład. No i (siostrą) się tak zajmowałam, ją nie wiem jakoś po prostu tak miałam w głowie, że chcę ją wychować, żeby ona w ogóle no wyszła na ludzi, nie? (kobieta, 29 lat).

W przypadku osób parentyfikowanych opieka nad rodzeństwem rozszerza się do przejmowania funkcji wychowawczych. Wiąże się to zarówno z poczuciem odpowiedzialności za zwykle młodsze rodzeństwo, jak i z zaspokajaniem jego potrzeb i troską o jego przyszłość, co powinno być przypisane rodzicom i rolom rodzicielskim.

7. Dziecko jako osoba prowadząca gospodarstwo domowe.

Zawsze ja byłam tą odpowiedzialną, tą, co ugotuje, posprząta, wypierze (...). No uważam, że to takie niesprawiedliwe, bo jak siostra się bawiła tam z kuzynką (...), to ja w tym czasie prałam, gdzieś tam gotowałam czy odgrzewałam obiad, który został. Potem trzeba było się uczyć i jakoś tej zabawy było mniej (kobieta, 27 lat).

W sytuacji narzucania dziecku nadmiernych obowiązków, niejako przerzucania na nie instrumentalnej odpowiedzialności za funkcjonowanie gospodarstwa domowego, staje się ono tzw. Kopciuszkiem, który traci możliwość realizacji swoich potrzeb lub zostają 
mu one mocno ograniczone. Badani wskazują na brak czasu na zabawę i ograniczony kontakt $\mathrm{z}$ rówieśnikami. W wielu przypadkach narzucane obowiązki przekraczały siły, a nawet umiejętności dziecka. Mimo to starało się ono je wypełnić, by zadowolić rodziców, zasłużyć na ich uwagę, wesprzeć ich w prowadzeniu domu lub poczuć się potrzebnym. Nie zawsze następowała oczekiwana gratyfikacja w postaci pochwały czy dostrzeżenia wysiłku dziecka.

Wskazane role realizowane przez dziecko generują niejako określone zachowania, postawy czy zjawiska. Dziecko stające się jeszcze w dzieciństwie osobą dorosłą musi samodzielnie się wyposażyć w atrybuty właściwe dorosłym. Zmuszone jest w takich okolicznościach stawać na wysokości zadania, przekraczać swoje możliwości oraz kształtować niezbędne kompetencje.

\section{Zjawiska towarzyszące parentyfikacji}

Analizowane narracje pozwalają na wskazanie działań podejmowanych przez badanych oraz zjawisk czy procesów występujących w rodzinie, które towarzyszą odwróceniu ról lub są przez nie wywoływane. Na uwagę zasługuje fakt, że dziecko może funkcjonować w podwójnej roli rodzicielskiej: wobec rodzeństwa i względem rodziców. Osoby parentyfikowane wypełniają funkcje opiekuńcze - zaspokajają potrzeby ojca czy matki, stając się ich oparciem, a także zajmują się wychowywaniem rodzeństwa, niekiedy wręcz zastępując rodziców. Zgromadzone w toku badań narracje wskazują na kolejny istotny aspekt w tym zakresie, który roboczo określamy tu jako „samowychowanie”. Chodzi o swoiste zajmowanie się samym sobą. Dzielne dziecko, jakim zwykle jest czy była osoba parentyfikowana, zostaje zmuszone do samodzielnego zaspokajania własnych potrzeb lub całkowitego zapomnienia o nich, przedkładając nad nie potrzeby najbliższych. Ciężar odpowiedzialności składany na barki dziecka, obiektywnie rzecz biorąc, zazwyczaj znacząco przekracza jego możliwości rozwojowe i siły. Jest to w wielu przypadkach konieczność wynikająca ze wzajemnych więzi rodzinnych, lojalności, a niekiedy wyraźnie formułowane wobec dziecka wymagania i oczekiwania. Staje ono przed zadaniem utrzymania rodzinnego ładu, przejęcia odpowiedzialności za cały system rodzinny - kieruje do siebie samego jeden ważny przekaz/nakaz: „Muszę sobie poradzić!” (kobieta, 35 lat). Bez wsparcia emocjonalnego czy instrumentalnego od dorosłych dziecko staje się niczym mitologiczny Syzyf, wtaczający głaz pod górę, mozolnie, powoli, próbując utrzymać kontrolę nad sytuacją. W rzeczywistości wielokrotnie ową kontrolę traci w obliczu sytuacji niespodziewanych, kryzysowych, którym jako dziecko (nawet $\mathrm{w}$ roli rodzica) nie jest w stanie sprostać. 


\section{Konsekwencje indywidualne i rodzinne}

Opowieści - narracje o życiu - stanowią indywidualne spojrzenie rozmówcy (narratora) na swoje doświadczenia z perspektywy czasu i w sposób całościowy. W każdym niemal wywiadzie można dostrzec swego rodzaju autoanalizę czy autorefleksję nad swoim życiem. W toku narracji sami badani dostrzegali konsekwencje odwrócenia ról rodzinnych. Wskazywano na negatywne skutki parentyfikacji towarzyszące czy przejawiające się w sposób długotrwały w życiu dorosłym. Jednakże rozmówcy podkreślali również pozytywny jej aspekt, wyróżniając wiele korzyści wynikających z owej konieczności bycia dorosłym już w dzieciństwie, które w ich ocenie pomogły w ukształtowaniu korzystnych cech i umiejętności. Wśród konsekwencji pozytywnych na uwagę zasługują: wypracowanie zdolności do radzenia sobie w każdej sytuacji, samodzielność, zaradność, odpowiedzialność za siebie i za innych, umiejętność dążenia do założonego celu, pracowitość, bardzo dobra organizacja, samodyscyplina, zdolność do poświęceń. Wymienione cechy czy przymioty analizowane oddzielnie są same w sobie niewątpliwie cenne i pożądane (cenione społecznie). Jeśli jednak je rozpatrywać w kontekście całego życia, a zwłaszcza doświadczenia parentyfikacji, można zauważyć, że stanowią rezultat konieczności poradzenia sobie z trudną sytuacją rodziny. Dziecko, na którego barki zrzucona zostaje odpowiedzialność za cały system rodzinny, zostaje niejako zmuszone do wypracowania mechanizmów radzenia sobie z nią. Rozmówcy dostrzegają ten dysonans i podwójną interpretację pozytywnych, wydawałoby się, cech.

W ten sposób sobie też radziłam z problemami, właśnie uciekałam w sport, w pracę. No jakoś sobie musiałam z tym poradzić, więc to był mój sposób - i dobrze, i niedobrze. Dobrze dlatego, że udało mi się coś tam osiągnąć w życiu, myślę całkiem nieźle, jak na - że tak powiem - start, jaki miałam. $\mathrm{Z}$ drugiej strony niedobrze, bo na przykład do dziś nie umiem odpoczywać i to jest mój problem (kobieta, 35 lat).

Jako konsekwencje wyraźniej negatywne, przejawiające się w konkretnych trudnościach czy nawet zaburzeniach $\mathrm{w}$ dorosłym życiu, na podstawie otrzymanych narracji należy wskazać:

1. Bycie ciaggym opiekunem dla każdego, nieumiejętność tworzenia relacji partnerskich, poszukiwanie takich towarzyszy życia, o których będzie można się troszczyć przy jednoczesnym „spychaniu” własnych potrzeb na dalszy plan.

2. Poczucie winy towarzyszy „dorosłym dzieciom” z różnych powodów, np. w sytuacji odcięcia od rodziny, rozpoczęcia nowego życia pojawia się poczucie winy, że „korzysta się z życia”. Inną sytuacją jest poczucie winy wyłaniające się z myślenia, że zrobiło się za mało, jako dziecko nie sprostało się oczekiwaniom.

3. Zaburzone lub utrudnione relacje $\mathrm{z}$ rodzeństwem $\mathrm{w}$ dorosłym życiu są skutkiem owego zaburzonego układu ról rodzinnych. Dziecko parentyfikowane nie mogło być rodzeństwem, a musiało pełnić funkcje rodzicielskie, co w percepcji młodszego rodzeństwa mogło wydawać się niezrozumiałe, a w konsekwencji powodować 
konflikty i napięcia. Relacje w dorosłym życiu pozostają skomplikowane, rodzeństwo nie do końca wie, kim dla siebie jest.

4. Destrukcyjne poczucie odpowiedzialności przejawia się rezygnacją z własnych planów, marzeń, pasji, możliwości rozwoju - z własnego życia - na rzecz opieki, utrzymania więzi z rodziną pochodzenia, rodzicami, emocjonalnym i materialnym zniewoleniem, poczuciem obowiązku wspierania rodziców i rodzeństwa.

5. Poczucie żalu do rodziców z powodu narzucenia dziecku obowiązków ponad jego siły oraz braku wspierającej relacji z nimi - ów żal jest wyraźnie artykułowany przez rozmówców. Stanowi powód swego rodzaju niepokoju, a zarazem strachu przed powtórzeniem błędów rodziców. Wiąże się to również z asekuracyjną, często zdystansowaną postawą względem własnych dzieci.

Powyższe konsekwencje stanowią zaledwie fragment całego wachlarza. Te obserwowane i wskazywane przez uczestników badań można traktować jako znaczące dla nich samych. Doświadczenie parentyfikacji stanowi rodzaj brzemienia noszonego również w dorosłym życiu. Jest to w istocie problem „dorosłych dzieci”, którym niejako odebrana została część dzieciństwa. Okoliczności rodzinne zmusiły je do odsunięcia na dalszy plan jakiegokolwiek pragnienia realizacji własnych potrzeb właściwych dla tego etapu życia. Wymienione konsekwencje mają charakter ogólny, przy czym należy podkreślić, że zarówno one, jak i sam przebieg zjawiska parentyfikacji są wypadkowymi wielu okoliczności i sytuacji mających miejsce w środowisku rodzinnym.

\section{Podsumowanie - inspiracje dla pracy socjalnej}

Parentyfikacja ma charakter ukryty, gdyż zazwyczaj stanowi wewnętrzny mechanizm rodzinny, będący jej sposobem na przetrwanie. Przedstawione tu refleksje mogą stać się przyczynkiem do podjęcia szerszych i pogłębionych badań nad procesami zachodzącymi w rodzinie, a szczególnie nad odwracanym porządkiem ról wewnątrzrodzinnych. Jednakże biorąc pod uwagę perspektywę osób parentyfikowanych, ukazujących własne doświadczenia w toku narracji, należy dostrzec wartość i znaczenie dla pracy socjalnej tak pozyskiwanej wiedzy na temat tego zjawiska. Jej znaczącym zadaniem jest bowiem praca z rodziną, której skuteczność zależy w znacznej mierze od świadomości owych mechanizmów i procesów zachodzących w środowisku rodzinnym. Zaprezentowane w niniejszym artykule zjawisko parentyfikacji może stanowić jeden z wielu problemów rodziny, z którym ma do czynienia pracownik socjalny. Może być zarówno przyczyną, jak i skutkiem trudnej sytuacji całego systemu rodzinnego. Oznacza to zatem, że praca socjalna w rodzinie, z rodziną i dla rodziny (Kanios 2016) powinna uwzględniać taką perspektywę. Wymaga to szerokiego spojrzenia na środowisko rodzinne i dogłębnej analizy jego sytuacji. Nieznane, często nieuświadomione zjawisko odwrócenia ról rodzinnych stanowi coraz większe wyzwanie dla osób podejmujących współpracę $\mathrm{z}$ rodziną. 


\section{Bibliografia}

Becker S. (2007). Global perspectives on children's unpaid caregiving in the family. „Global Social Policy", 7, 1: 23-50.

Earley L., Cushway D. (2002). The parentified child. „Clinical Child Psychology and Psychiatry”, 7/2: 163-178.

Grzegorzewska I. (2016). Parentyfikacja w rodzinach z problemem alkoholowym. „Alcoholism and Drug Addiction", 29: 27-38.

Haxhe S. (2016). Parentification and related processes: Distinction and implications for clinical practise. „Journal of Family Psychotherapy”, 27 (3): 185-199.

Kanios A. (2016). Praca socjalna $z$ rodzina problemowa. Perspektywa metodyczna. Oficyna Wydawnicza „Impuls”, Kraków.

Lalak D. (2010). Podejście biograficzne (biograficzność) w naukach o wychowaniu. Trzy perspektywy dyskursu, w: S. Palka (red.), Podstawy metodologii badań w pedagogice. Gdańskie Wydawnictwo Psychologiczne, Gdańsk.

Minuchin S. (1974). Families and Family Therapy. Harvard Press, Boston; Tavistock, London.

Minuchin S., Montavalo B., Guerney jr B.G., Rosman B.L., Schumer F. (1967). Families of the Slums: An Exploration of their Structure and Treatment. Basic Books, New York.

Rostowska T., Borchet J. (2016). Proces parentyfikacji w kontekście teorii systemowej. „Roczniki Pedagogiczne”, 8 (44), 3: 5-21.

Schier K. (2012). „Gdy dziecko staje się rodzicem” - odwrócona troska, czyli zjawisko parentyfikacji $w$ rodzinie, w: B. Tryjarska (red.), Bliskość $w$ rodzinie. Więzi $w$ dzieciństwie a zaburzenia $w$ dorosłości. Wydawnictwo Naukowe SCHOLAR, Warszawa.

Schier K. (2015). Dorosłe dzieci. Psychologiczna problematyka odwrócenia ról w rodzinie. Wydawnictwo Naukowe, Warszawa.

Trzebiński J. (red.) (2002). Narracja jako sposób rozumienia świata. Gdańskie Wydawnictwo Psychologiczne, Gdańsk.

Urbaniak-Zając D., Kos E. (2013). Badania jakościowe w pedagogice. Wydawnictwo Naukowe PWN, Warszawa.

Żarczyńska-Hyla J., Zdaniuk B., Piechnik-Borusowska J., Karcz-Taranowicz E., Kromolicka B. (2016). Uwarunkowania parentyfikacji doświadczanej w dzieciństwie i okresie dorastania z perspektywy młodych dorosłych. „Rocznik Andragogiczny”, 23: 199-216. 